REVISTA DE DERECHO UNED, NÚM. 24, 2019

\title{
ESTADO Y KATÉCHON: LA DESPOLITIZACIÓN DE LO POLÍTICO Y LA POLITIZACIÓN DE LO HUMANO
}

\author{
STATE AND KATÉCHON: THE DEPOLITICIZATION OF THE \\ POLITICAL AND THE POLITICIZATION OF THE HUMANNESS
}

Francisco de Borja Gallego Pérez de Sevilla

Doctorando en el Departamento de Filosofía Jurídica

(Universidad Nacional de Educación a Distancia)

Resumen: Este trabajo tiene por objeto el estudio, en primer lugar, de la figura teológico-política del katéchon en paralelo con la del Estado como garante de la paz, en la medida que ambos manejan una idea de barrera contra el mal. En segundo, analizar la construcción de un gran espacio universal estatalizado que opera miméticamente como una suerte de remedo artificial y secularizado del imperio cristiano ante la idea apocalíptica del fin de los tiempos.

Palabras clave: Imitación, imperio, katéchon, subjetivismo, voluntarismo, Estado.

Abstract: The purpose of this paper is the study, first of all, of the theological-political figure of the Kathechon in parallel with the State as guarantor of peace, as both handle an idea of a barrier against evil. Secondy, to analyze the construction of a great nationalized universal space that operates mimetically as a sort of artificial and secularized imitation of the Christian empire due to the apocalyptic idea of the end of time.

Keywords: Imitation, empire, katéchon, subjectivity, voluntarism, State.

Recepción original: 04/02/2019

Aceptación original: 27/02/2019

(C) UNED. Revista de Derecho UNED, núm. 24, 2019 
Sumario: I. Introducción. II. El Imperio y la nación. III. El Estado como katéchon. IV. La misión soteriológica del Estado. V. La despolitización de lo político y la politización de la naturaleza humana. VI. La era de la imitación. VII. Conclusiones. VIII. Biblografía

\section{INTRODUCCIÓN}

El concepto de imperio asociado al de resistencia o contención del mal en el mundo posee una significación teológico-política inextricable. Este misterio de la iniquidad plantea un drama escatológico que presupone la parusía de Cristo y el fin de los tiempos que acontece tras la gran apostasía universal y la aparición del hijo del pecado, denominado como Anticristo por San Juan. A este respecto, San Pablo añadió específicamente la cláusula del katéchon ${ }^{1}$, una figura teológica expresada por vez primera en la segunda carta a los tesalonicenses. Siguiendo a Buela Lamas², el contexto de la misiva paulina es el siguiente:

«En la Iglesia de Tesalónica habían sucedido disturbios a consecuencia de la creencia que la segunda venida de Cristo era inminente. Esta señal era perteneciente parcialmente a unos malos entendidos de la $1 .^{a}$. de Tesalonicenses (4:15 y sigs.), parcialmente a las maquinaciones de los impostores. Fue como una forma de remediar éstos desórdenes que San Pablo escribió su segunda epístola a los Tesalonicenses, introduciendo específicamente en los versículos 6 y 7 su doctrina del katechon como un complemento a su visión apocalíptica.»

El texto apocalíptico completo dice así:

«Hermanos, os suplicamos, por el advenimiento de nuestro Señor Jesucristo y de nuestra reunión con él, que no abandonéis ligeramente vuestros sentimientos, ni os alarméis con supuestas revelaciones, con ciertos discursos o con cartas que se suponga enviadas por nosotros, como si el día del Señor estuviera ya cercano. Que nadie os engañe en manera alguna. Porque antes ha de venir la apostasía y se ha de manifestar el hombre de la iniquidad, el hijo de la perdición. El cual se opondrá y se alzará contra todo lo que se dice Dios, o es objeto de culto, hasta llegar a sentarse en el mismo templo de Dios, dando a entender que es Dios.

${ }^{1}$ De katécho que significa: retener, agarrar, impedir ( nizarse como katechon y pronunciarse katéjon, es el participio o presente del verbo

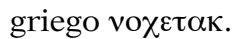

2 Buela Lamas, Alberto. 2008. "El katéchon como idea metapolítica». Última modificación 18 de noviembre de 2008. http://euro-synergies.hautetfort.com/archive/2008/11/18/el-katechon-como-idea-metapolitica.html 
Vosotros sabéis lo que ahora lo detiene (to katéchon), de manifestarse a su tiempo. Porque el misterio de iniquidad ya está actuando. Tan solo sea quitado del medio el que ahora lo detiene (ho katéchon). Y entonces se dejará ver aquel inicuo a quien el Señor Jesús matará con el aliento de su boca y destruirá con el resplandor de su venida. Aquel inicuo que vendrá con el poder de Satanás, con todo poder, señales y prodigios falsos. Y con todo engaño de iniquidad para los que se condenan por no haber aceptado el amor de la verdad a fin de salvarse. Por eso Dios les enviará el artificio del error que les hace creer en la mentira. Para que sean juzgados todos los que no creyeron en la verdad, sino que se complacieron en la injusticia. (2 Tes 2, 1-12).»

La idea de dos personajes o escenarios opuestos - el katéchon y el anomos-dibuja un complejo horizonte político-religioso que ha sido estudiado con diversas interpretaciones, que sin embargo no serán objeto de estudio por parte de este trabajo. No obstante, y siendo conscientes de las humildes pretensiones del mismo, se tratará de ofrecer, en el marco de la tesis y las hipótesis que aquí sostendremos, una idea aproximada de qué o quién es el katéchon.

Una tesis que, como veremos, estribará en una dialéctica de mímesis entre el katéchon y el Estado, en un escenario en el que aquel ha sido falseado y sustituido por un katéchon político, que ya no retiene o demora el mal sino que solo lo enmascara, o en todo caso, que retiene una idea de mal adecuada al modo de pensar fruto de la sacralización de lo político y de la divinización del hombre en el contexto del voluntarismo jurídico de la posmodernidad.

\section{EL IMPERIO Y LA NACIÓN}

Frente a la idea de nación propia del modo de pensamiento estatal, la idea de imperio sugiere un concepto de carácter espiritual. No se expresa exclusivamente sobre un territorio, y pese a tener consecuencias jurídico-políticas, constituye algo cualitativamente diferente y superior. Según la definición de Carl Schmitt, el imperio propone la ordenación del espacio con la exclusión de potencias alógenas. El imperio es una idea rectora que irradia una noción política sobre un gran espacio. Para el autor, el imperio es un instrumento destinado a re-politizar la existencia; un coto contra la neutralización del Estado total y cuantitativo de partidos, frente al cual propone un Estado cualitativo ${ }^{3}$ y polí-

${ }^{3}$ Contrarrevolución o resistencia: la teoría política de Carl Schmitt , JIMÉNEZ SEGADO, Carmelo. Tecnos, Madrid, 2009, pp. 146-147.

(C) UNED. Revista de Derecho UNED, núm. 24, 2019 
tico basado en la decisión sobre el estado de excepción, que opera análogamente al milagro ${ }^{4}$.

Del mismo modo, la idea de imperio en Schmitt supone un obstáculo contra la universalidad de las grandes potencias y la tendencia hacia la construcción de un mundo unipolar, el verdadero mal. Las relaciones de los grandes espacios estarían reguladas por el derecho internacional que operaría bajo la misma alteridad que se deduce de la dialéctica amigo-enemigo propia del derecho de gentes. Nótese que la idea de irradiación sugiere la ligazón del imperio con un orden cósmico y moral. En este sentido el imperio es la creencia ancestral de la unidad lógica de la tierra y de un solo emperador, un rey de reyes. El orden humano debe reflejar y replicar el orden cósmico y su voluntad supra-política sobre el mundo. De ahí que el imperio sea una idea reguladora, entendida más como una autoridad moral que como un poder, puesto que la naturaleza del imperio es eminentemente sagrada por referirse a este orden cósmico, y su legitimidad supra-convencional al estar ligada al orden universal de las cosas. El problema del imperio viene dado por la ausencia de límites, lo que - al contrario que sucede en el pensamiento de Schmitt- sugiere un tipo de forma política anti-política, así como lo es el Estado, aunque por causas distintas. El Estado es neutral porque se arroga el ejercicio del poder y hace de éste una mera técnica fáctica de auto-conservación. En esencia, el Estado neutraliza lo político y el modo de pensar político, que nunca es neutral. En el caso del imperio, dado que lo político limita con la filosofía, con lo sagrado y con la guerra, y el imperio presupone la paz, lo político llega a su fin. Etimológicamente, lo político es lo propio de la polis como unidad de organización cerrada, y ello incluye la guerra contra otras polis. La tendencia del imperio es de expandirse sobre otras formas políticas y a la asunción de las mismas, lo que implica una situación de paz duradera.

La restauración hobbesiana supone la revisión geométrica ${ }^{5}$ del mito de la polis a través del Estado, que opera como unidad cerrada y particularista de poder frente a la tradición política europea heredada de la res-publica romana. Por eso es incompatible con el imperio. Por cierto que la república no es incompatible con la monarquía. La república describe la cosa pública que es la esencia de lo político, siendo lo político en sí mismo una esencia. Y esa esencia re-

${ }^{4}$ Teología Política, SCHMITT, Carl. Trotta, Madrid, 2009, p. 37.

5 Para la explicación geométrica del Estado hobbesiano y su relación con el soberano, ver de Gallego, Autoridad y Razón: Hobbes y la quiebra de la tradición occidental, GALLEGO, E. Estudios Políticos, Madrid, 2016. 
side en la organización y en la custodia del orden social. El político conserva y hace cumplir el derecho, por eso es una potestad distinta a la del juez, que lo restaura. Sería Monstequieu el que bajo el modo de pensar estatal definiría la incompatibilidad entre monarquía y república. El relato de la restauración de la polis como un ser vivo supone la ontologización del Estado tras la Revolución Francesa como una entidad subjetivada, cuya metafísica es compartida por la nación, una unidad colectiva y sociológico-moral hipostasiada. Es decir, devenida en sujeto activo de lo político, cuya voluntad jurídica no solo atañe a la política sino también a la moral. Este proceso de ontologización y radicalización del Estado hallará su cúspide con la eticidad hegeliana:

«El Estado es la realidad efectiva de la idea ética, el espíritu ético como voluntad sustancial revelada, clara para sí misma, que se piensa y que se sabe y cumple aquello que sabe precisamente porque lo sabe (...) En cuanto realidad de la voluntad sustancial, realidad que ésta tiene en la autoconciencia particular elevada a su universalidad, el Estado es lo racional en y para sí. Esta unidad sustancial es auto finalidad absoluta, inmóvil, donde la libertad llega a su derecho supremo, así como esta finalidad última tiene el derecho supremo frente a los individuos, cuyo deber supremo es ser miembros del Estado ${ }^{6} . »$

\section{Con referencia a esto, también señala Schmitt:}

«Mientras se conservó la idea de Dios, la filosofía de la inmanencia, cuya magnífica arquitectura culmina en la filosofía de Hegel, refiere Dios al mundo, y el derecho y el Estado se dejan brotar una inmanencia de lo objetivo. En los radicales más extremistas domina un ateísmo consecuente ${ }^{7} . »$

En la ecuación derivada de la relación entre el imperio, el Estado y la nación, queda por responder la cuestión relativa a la Iglesia, que opera como reino espiritual, pero como institución humana, está en el mundo ${ }^{8}$. La Iglesia desmitifica que lo divino esté en la naturaleza, pues lo divino no es histórico. La historia se produce con la irrupción del tiempo mediante un acto de voluntad divina, y se define por la tensión entre el logos naturalista heracliteano y el logos juánico del amor ${ }^{9}$,

${ }^{6}$ Fundamentos de la filosofía del derecho, HEGEL, Friedrich. Libertarias-Prodhufi, Madrid, 1993, pp. 678-679.

7 Schmitt, Carl: Teología...op. cit., p. 47

8 Apunta Schmit: «La Iglesia de Cristo no es de este mundo, y su historia, pero está en este mundo. Es decir; toma y da espacio, y "espacio" significa aquí: impermeabilidad, visibilidad y publicidad» Ibid., p. 87.

${ }^{9}$ En el famoso discurso de Ratisbona, Benedicto XVI se refiere a Dios como el «logos». Coincidiendo con René Girard, Dalmacio Negro apunta a la dialéctica entre el logos racional del Estado y el logos cristiano, un logos revolucionario en lucha constante contra la mitificación del mundo. 
que bien podría extrapolarse a la tensión entre el Estado y la Iglesia. Si bien para la Iglesia la historia de la humanidad es la historia de la Salvación y el fin último de la historia es Cristo, la historia del Estado viene marcada por la escatología intramundana, cuya meta también es la salvación pero dentro de los confines de lo político. Pero, ¿qué o quién es entonces el katéchon? ¿Es la Iglesia como communio espiritual? ¿Es el imperio como reflejo del orden cósmico? ¿O es el Estado como construcción técnica para la neutralización del conflicto? Trataremos de dar respuesta a estas cuestiones en el siguiente apartado.

\section{EL ESTADO COMO KATÉCHON}

La naturaleza espiritual del katéchon es opaca; no es inteligible para la gnosis humana allende la mera especulación teológica. No es una hueste celestial, no está compuesta por ángeles ni arcángeles, sino, antes bien, es un instrumento humano puesto por la cristiandad al servicio de la comunidad política que opera como centro neurálgico de todo acontecer humano. Tampoco está fijado en el tiempo, puesto que presupone, como indica Agamben, un «ya» y un "todavía no", ${ }^{10}$ es decir, algo que está ocurriendo pero que todavía ha de esperarse, un tiempo mesiánico, «el tiempo de ahora», entendido no como el fin de los tiempos sino como el tiempo del fin ${ }^{11}$. El drama escatológico del katéchon dibuja una teología de la historia, una res mixtae ubicada entre la primera y la segunda venida de Cristo $^{12}$, cuya solución ha de dirimirse en el fin de los tiempos como dilación del Apocalipsis, y sin embargo proclama y reivindica su rabiosa actualidad en el mundo a través de instituciones jurídicas de pleno constituidas como el imperio, pero también la Iglesia ${ }^{13}$.

Cuando Carl Schmitt se refería al katéchon como la barrera contra el Anticristo, estaba imaginando el imperio alemán como un heredero legítimo del Sacro Imperio ${ }^{14}$, que venía a restablecer la

${ }^{10}$ El misterio del mal: Benedicto XVI y el fin de los tiempos, AGAMBEN, Giorgio. Adriana Hidalgo Editora, Buenos Aires, 2013, p 54. Apunta el autor que ese escenario escatológico «no se trata de una estructura temporal abstracta, sino de un drama o de un conflicto en el que actúan fuerzas históricas absolutamente concretas. El «no todavía» se refiere a la acción del katéchon, de la fuerza que retiene; el "ya» se refiere a la urgencia del elemento decisivo».

11 Ibid., p. 27.

12 Schmitt, Carl, Teología...op. cit,. p. 121.

13 Agamben, Giorgio, El misterio...op. cit., p. 51.

14 Jiménez Segado, Carmelo, Contrarrevolución...op. cit., p. 201. 
unidad política y religiosa originaria ${ }^{15}$. Esta tesis, con evidentes reminiscencias teológico-políticas del pensamiento donosiano sobre la legitimidad del imperio católico sobre el mundo y la sociedad en general, y sobre la necesidad de la decisión - y con ella la dictadura $^{16}$ - en concreto, ha sido en general malinterpretada como una justificación del régimen nazi sobre el resto Europa ${ }^{17}$.

Lo que realmente preocupaba a Schmitt era la sustitución de los grandes espacios-comúnmente confundida con la teoría nacional-socialista del espacio vital por un one world polarizado por dos bloques netamente anti-políticos, uno por democrático y liberal, y otro por comunista y anticristiano. La idea de imperio en el jurista nacido en Plettenberg radicaba en la re-politización de los grandes espacios y en la necesidad de establecer un dique que frenase la neutralización del Estado, cuya política partidista y su falta de capacidad de decisión era incompatible con la tesis de Schmitt ${ }^{18}$. Porque ni el Estado, ni ninguna suerte de organización o alianza supra-estatal, pueden ser el katéchon. Si nos atenemos a la carta de San Pablo, debe existir por sí solo, no es el resultado de ninguna fuerza política o jurídica artificial como la estatal. Y el Estado, que pretende ser katéchon del mismo modo que pretende ser ekklesía, es necesariamente artificial y revolucionario en un sentido opuesto al cristianismo. El cristianismo es revolucionario por separar el poder espiritual del temporal, así como por introducir en el mundo el perdón de los pecados mediante el sacrificio, y el Estado es revolucionario por transformar constantemente la realidad social y politizar la naturaleza humana. Pero la imitación que reproduce el Estado fijándose en la Iglesia es comparable con la imitación que hace del katéchon. No obstante, resulta arriesgado afirmar categóricamente que aquel es la Iglesia como comunidad sobrenatural, que actúa como depositaria universal de los bienes espirituales. Aunque ciertamente opera en el mundo como una forma política, y en este sentido es imperial por reflejar el orden cósmico, no es per se política, puesto que es una communio, una comunión espiritual, lo que representa una dualidad ontológica. Por otro lado, si el Estado fuese el katéchon, solo existi-

15 Ibid., p.203.

${ }^{16}$ Escribe Schmitt: «Cuando Donoso Cortés vio que la monarquía tocaba a su fin, porque ni reyes había ya, ni nadie con valor para serlo sin contar con la voluntad del pueblo, sacó la consecuencia última del decisionismo, es decir, reclamó la dictadura política» Schmitt, Carl, Teología...op. cit., p. 57.

${ }_{17}$ El propio Carmelo Jiménez Segado, que aquí hemos citado, es recurrente en su crítica a Schmitt como un justificador del nacional-socialismo bajo el halo de legitimidad moral que le proporcionaba la teología católica.

18 «Schmitt, Carl, Teología...op. cit., p. 53. 
ría el mal fuera de las fronteras del Estado, o en todo caso el mal sería encarnado por otro Estado.

Sin embargo, que el Estado sea el katéchon alberga la posibilidad de que el mal, entendido no tanto como enemigo del cristianismo sino como su principal imitador, habite en su interior disfrazado de un poder legítimo, protegido por la propia legalidad estatal. Esto ocurriría incluso dentro de la Iglesia, de tal modo que el katéchon, antes de contener el mal, estaría enmascarándolo no solo dentro de los límites de lo político, sino dentro del seno mismo de la cristiandad. Algo decisivo según la tesis de Agamben para la «gran renuncia» de Benedicto XVI, entendida por el teólogo italiano no como un acto de cobardía, sino como de resistencia contra el mal en la Iglesia, puesto que «sacó a la luz el misterio escatológico en toda su fuerza disruptiva ${ }^{19}$, en referencia a la naturaleza mixta de la Iglesia. Bajo el punto de vista escatológico la Iglesia escapa del mundo, y desde el punto de vista económico, es del mundo. De ahí la paradoja que sugiere la "gran diccesio», es decir, la gran separación entre malvados y fieles, entre la Iglesia como cuerpo del Anticristo y como el cuerpo de Cristo que supone la condición bipartita que la divide entre la santidad y el pecado ${ }^{20}$.

La Iglesia entendida como katéchon, dada esa dicotomía ontológica entre lo mundano - económico ${ }^{21}$ - y lo escatológico, estaría demorando la llegada del mal pero no deteniéndola, puesto que la imitación de la anomia no puede ser infinita en el tiempo, y es de esperar para el cristianismo que los misterios escatológicos sean desvelados con el fin de la imitación y el desenmascaramiento del anomos, el sin ley. Este acontecimiento mediante el cual el anomos queda revelado, es aguardado por la cristiandad en la parusía, que conforme la tesis de Agamben - recogiendo el material original del teólogo Ticonio, imprescindible en San Agustín para la escritura de La ciudad de Dios-, es un fenómeno que tendría lugar en la misma Iglesia, dada a esta naturaleza permixta de bien y mal, entre lo mundano y lo espiritual.

19 Agamben, Giorgio, El misterio...op. cit., p.30.

${ }^{20}$ Ibid., p.25.

${ }^{21}$ El reino y la gloria: por una genealogía teológica de la economía y el gobierno, AGAMBEN, Giorgio., Pre-Textos, Valencia, 2008, pp. 39-42. El teólogo italiano estudia el sentido de la palabra oikonomia en relación a los textos bíblicos y su significación como ordenación o administración doméstica de la comunidad mesiánica. El propio San Pablo aparece como encargado de esa "economía» del misterio adecuada a la resolución de un "plan divino» o salvífico, aunque el propio Agamben subraya la ambigüedad de esa interpretación. 
«Según Ticonio, el cuerpo de Cristo, o sea, la Iglesia, está constitutivamente dividido (...) él distingue una Iglesia negra, compuesta por el populus malus de los malvados, que forman el cuerpo de Satanás; y una Iglesia decora, honesta, compuesta por los fieles de Cristo. En el estado actual, los dos cuerpos de la Iglesia se encuentran inseparablemente entremezclados pero, - de acuerdo con la predicción del Apóstol- se dividirán al final de los tiempos ${ }^{22}$.»

Señala Agamben que para Ticonio existe un tiempo escatológico, desde la Pasión de Cristo hasta la separación de los dos cuerpos de la Iglesia, donde se revela el misterio del mal, lo que sugiere efectivamente la existencia de una corriente de pensamiento que sitúa a la Iglesia como katéchon, lo que es del todo incompatible con la revisión estatalizada del katéchon donde no existe ya una dialéctica teológica entre el bien y el mal, sino una absoluta neutralización donde el mal es absorbido jurídicamente.

A este respecto, cabe afirmar que la fórmula del Schmitt no sugiere efectivamente un katéchon basado en la imitación del Estado, puesto que la idea de imperio germánico soluciona esta especulación; son las naciones europeas cristianas las que, bajo la forma política del imperio, constituyen un bastión frente al mal. Para el jurista de Plettenberg la misión del katéchon descansa en el emperador y en la Respublica Christiana que opera como nomos o unidad jurídica medieval de los reinos cristianos ${ }^{23}$. Lo contrario al nomos, la norma, es la anomia, la no-ley, el anticristo. La misión del katechon solo tendrá éxito si se perpetúa en el tiempo reteniendo al mal hasta el fin del eón cristiano:

«El concepto decisivo de su continuidad, de gran poder histórico, es el del Kat-echon. Imperio significa en este contexto la fuerza histórica que es capaz de detener la aparición del anticristo y el fin del eón presente, una fuerza qui tenet (...) El imperio de la Edad Media cristiana perdura mientras permanece activa la idea de Kat-echon ${ }^{24}$.»

La legitimidad del imperio y del katéchon descansa en la tradicional distinción y cristiana entre auctoritas y potestas, entre la autoridad espiritual y el poder temporal, asumidos por el papado y el imperio respectivamente ${ }^{25}$. La perturbación de este equilibrio de poder genera la tiranía, donde el emperador fracasa en su misión como katéchon al no estar refrendado su poder por la autoridad moral de la Iglesia católica. A esta tiranía se refiere Schmitt como cesarismo,

${ }^{22}$ Agamben, Giorgio, El misterio...op. cit., p.41.

${ }^{23}$ El nomos de la tierra en el Derecho de Gentes "Jus publicum europaeum», SCHMITT, Carl. Editorial Struhart \& Cía, Argentina, p.38.

${ }^{24}$ Ibid., pp.40-41.

25 Ibid., pp.41-42. 
«una típica forma de poder no cristiano» ${ }^{26}$, y al mismo tiempo una fórmula necesaria para el éxito del proceso de secularización que conduce a la modernidad. Proceso por cierto inextricable al Estado como forma de poder particular y monolítica, que genera su propia religión laica y su particular moral pública, actuando como ekklesía temporal en el mundo, y por lo tanto con su propia misión salvífica así como su propia idea de mal en el mundo ${ }^{27}$. Pero sobre esto volveremos más adelante.

Para el éxito de su misión el katéchon debe conservarse en el tiempo a través del orden político cristiano. Pero el Estado, al rivalizar por imitación con la Iglesia, no es el katéchon que imaginaba Schmitt, puesto que no retiene al anomos. La carta de San Pablo sugiere la distinción entre el quid detineat (hó katechon, to katéchon,) y el hombre de la anomia, el sin ley (ho ánthropos tés anomías; homo pecatti en la Vulgata ${ }^{28}$ ): es decir, dos personajes o escenarios opuestos: aquel $-\mathrm{O}$ aquello- que retiene y lo que obstaculiza o demora, oculto en el mundo, imitando el quid detineat, al katéchon.

San Pablo se refiere al mysterium iniquitatis al afirmar que ya está actuando en el mundo, retenido por el to katéchon. Y cuando el to katéchon, el obstáculo, se desenmascare, el hijo de la anomia será revelado. San Pablo insiste en la naturaleza imitadora del anomos, lo que sugiere que el Estado, como remedo secular del katéchon, opera del mismo modo a través de las ideologías, que son religiones seculares de lo político. Como tales, éstas manejan una lógica imitadora al presentar una teleología utópica de salvación, un paraíso secular en la tierra y una misión soteriológica contenida en una escatología intramundana e inmanentista encerrada en los límites de lo político. El Estado imita al katéchon y enmascara así la anomia, al mismo tiempo que lucha contra su propia concepción del pecado, de naturaleza política. Imita al katéchon porque actúa como ekklesía temporal y presupone la erradicación del mal y del pecado en el mundo,

${ }^{26}$ Ibid., p.44.

${ }^{27}$ Las religiones de la política, VOEGELIN, Eric. Trotta, Madrid 2014, p.56. Escribe el autor que: «la nueva ekklesía de halla en lucha contra la antigua, cristiana, y en tanto que querida por Dios debe imponerse sobre cualquiera otras pretensiones, que solo pueden entenderse como obra del Diablo. (...) El intento de mantener o producir una Iglesia cristiana universal como institución con personalidad propia se interpreta como obra de Satán. La Iglesia católica, en su pretensión de ascendente espiritual sobre todos los cristianos, es el reino de las tinieblas, cuyo objetivo es impedir la continuación directa de la idea de "pueblo de Dios" (...) El Estado es la Iglesia, y todo aquel que se constituya enemigo de la nueva ekklesía, del Leviatán, es Satán».

${ }^{28}$ Agamben, Giorgio, El misterio...op. cit., p. 36. 
y por ende la conquista de la paz absoluta. La idea de la imitación aparece explícitamente en la epístola paulina:

«Hermanos, os suplicamos, por el advenimiento de nuestro Señor Jesucristo y de nuestra reunión con él, que no abandonéis ligeramente vuestros sentimientos, ni os alarméis con supuestas revelaciones, con ciertos discursos o con cartas que se suponga enviadas por nosotros, como si el día del Señor estuviera ya cercano. Que nadie os engañe en manera alguna. Porque antes ha de venir la apostasía y se ha de manifestar el hombre de la iniquidad, el hijo de la perdición. El cual se opondrá y se alzará contra todo lo que se dice Dios, o es objeto de culto, hasta llegar a sentarse en el mismo templo de Dios, dando a entender que es Dios.»

En fin, el Estado, que es la fórmula absoluta de neutralización del conflicto, sugiere la resistencia contra el mal porque proporciona paz y liquida la situación de guerra civil, el famoso estado de naturaleza tan temido por Thomas Hobbes. La paz, que no es otra cosa que la ausencia de acontecimientos, y por lo tanto lo contrario al estado de excepción, es lograda dentro de las fronteras del Estado bajo las fórmulas del derecho estatal que neutralizan el modo de pensar discordante, sin óbice de que ese mismo derecho estatal esté revestido de una supuesta pluralidad ideológica. A la postre, aunque cambien de signo, las ideologías mantienen, como el Estado, su naturaleza mimética; operan, como ya mencionamos, bajo la forma de religiones seculares de lo político ${ }^{29}$. Su particular escatología presupone el exordio del apocalipsis entendido como el estadio final de un proceso de tránsito. Bajo una dialéctica de tensión con el cristianismo, se produce la mayor de todas las imitaciones, la de un nuevo tipo de hombre, engendrado ex nihilo producto de la alquimia ideológica, del materialismo científico y el nihilismo ateo. Este nuevo hombre se considera a sí mismo víctima y al mismo tiempo salvador de un mundo imperfecto que está en deuda con él. Porque el sacrificado, que siempre había sido el culpable, es ahora inocente, y bajo sus lemas empuña siempre el verbo de la discordia para saldar una deuda que cree contraída con el otro, cuya distinción se hace

${ }^{29}$ Resulta interesante la diferenciación que realiza Emilio Gentile entre religiones civiles y políticas, entendiendo las primeras como aquellas que son compatibles con la democracia y otras religiones confesionales, sin perjuicio de que estén exentas de los rasgos característicos de toda religión secular, a saber: exhibición de ritos y liturgias exclusivamente políticas, asunción de una hagiografía particular, la creencia de "pueblo escogido", culto al partido-ideología que opera como numen, etc. Las religiones políticas serían aquellas que son propias de regímenes totalitarios, incompatibles con otros modos de pensar e impuestas por la violencia física y no sólo jurídica. Para más detalle, consultar Politics as religions, GENTILE, Emilio. Traducción de George Saunton, University Press, Princetown, 2006. 
siempre bajo términos existenciales, sin perjuicio de que esta distinción esté revestida por la ideología igualitaria que no hace sino provocar tensión mimética entre los hombres, generando un conflicto que solo el Estado, que ora como deus ex machina ${ }^{30}$, es capaz de neutralizar.

Como corolario a este epígrafe, cabe decir que el hombre nuevo que surge por analogía cristológica solo es posible dentro de un katéchon que opere bajo la misma dinámica mimética. Y el Estado, que se presenta a sí mismo como custodio exclusivo de la paz de la sociedad civil, se arroga este papel y promete una parusía secular dentro de los confines de lo político. Devenido en to katéchon, el Estado ya no retiene el mal, solo lo demora o enmascara puesto que tal es su naturaleza imitadora.

\section{LA MISIÓN SOTERIOLÓGICA DEL ESTADO}

El Estado aborda y trata de solucionar mediante la política todas las cuestiones de la vida humana, incluyendo la muerte y la salvación. De ahí que su aparato técnico surja por la imitación de la curia papal como órgano administrativo de poder, rivalizando así con la Iglesia por la salvación de las almas. El proceso de secularización - o mejor dicho, de politización- entierra la metafísica tradicional bajo las nuevas concepciones teológicas de la política. La sociedad antropocéntrica se va construyendo alrededor de esta nueva idea de hombre nacida de la razón y del progreso. El Estado, el titán de lo político surgido artificialmente a través del contrato - que aun operaba bajo estandartes religiosos puesto que la idea de Estado no nace sin la Iglesia ${ }^{31}$ - , hace las veces de guardián del hombre estatal cuya escatología pretende encerrar la metafísica ultraterrena dentro de los confines materiales de lo político-intrahistórico. Esto comenzó a ser palpable en primeras mancomunidades religiosas de calvinistas que funcionaban bajo la idea utópica de un nuevo cielo y una nueva tierra ${ }^{32}$. Los calvinistas diseñaron una suerte de comunidad santa que debía operar como epicentro de todo acontecer humano, y cuya naturaleza no podía ser sino política. Pese a manejar

\footnotetext{
30 Schmitt, Carl, Teología...op. cit., p. 38.

31 Incluso en el plano estrictamente semántico, mucho antes de que Maquiavelo se refiriese a lo stato, la terminología eclesiástica ya manejaba el vocablo status, lo que es demostrativo una vez más de que la Iglesia era aquella inspiración de la sociedad perfecta a la que aspiraba ser el Estado.

${ }^{32} \mathrm{La}$ frase fue tomada textualmente del Apocalipsis por los radicales puritanos que aspiraban a construir el Reino de Dios en la Tierra.
} 
un ideal ascético, no había espacio para lo supra-mundano, y la salvación debía llegar a través de herramientas exclusivamente terrenales. Apunta Michael Walzer: «La lucha por una nueva comunidad humana en reemplazo del Edén perdido se convirtió en un asunto de actividad política concreta ${ }^{33}$.

Como vemos, lo político opaca lo espiritual, y sin embargo este primer esbozo de hombre nuevo es eminentemente espiritual: es el buen salvaje roussoniano, angelical, el hombre nuevo por naturaleza. La espiritualidad del hombre nuevo no desaparece por su condición de inmanente; antes bien, fija los fines escatológicos de su existencia dentro del mundo, pero los conserva. El hombre estatal - que no es otra cosa que el hombre politizado-, pese a surgir a costa de la cristiandad - como lo político, que surge de la cristiandad y a costa de ella-, es necesariamente ateo y al mismo tiempo necesariamente religioso. Esto podría parecer un oxímoron, pero el hombre nuevo está, al igual que el hombre tradicional, sometido a una dualidad insalvable: es ateo porque niega toda trascendencia extramundana y extracorpórea, es decir, aquella que promete la vida en el allende, y religioso porque esa trascendencia queda ahora, como decimos, contenida dentro de los límites temporales gestionados por la política. El hombre nuevo sigue, en el sentido original de la palabra religión, re-ligado al mundo terrenal, aunque la conexión no sea con lo divino sino con lo político, si bien lo político ahora está imbuido de divinidad. La dimensión escatológica del hombre nuevo es, por tanto, intramundana.

La Revolución Francesa fue el punto de inflexión en el que se produce el asalto ideológico y el giro ateiológico ${ }^{34}$ : Lo sagrado -la ubicación espacial de lo divino- no se encuentra ya en el Estado, como ocurría durante la era del absolutismo bajo la fórmula del derecho divino de los reyes. La irradiación de sacralidad no se produce ahora por un acto de voluntad divina de Dios al monarca, sino por un acto de voluntad política, y lo sagrado, se transfiere a la naciónEstado que opera como sujeto activo de lo político ${ }^{35}$, siendo la voluntad general la expresión de su subjetivación como nueva entidad ontológica con sustancia y voluntad política propia. Al final, la Nación

${ }^{33}$ La revolución de los santos: estudio sobre los orígenes de la politica radical, WALZER, Michael. Katz Editoriales, Madrid, 2008, p. 43.

${ }^{34}$ Historia de las formas del Estado, una introducción, NEGRO, Dalmacio. El Buey Mudo, Madrid, 2010, p.192. El término ateiológico es empleado por el profesor Dalmacio Negro para referirse al giro ideológico necesariamente ateo que se produce con la Revolución Francesa.

35 Ibid., p.229. 
Política nacida de la revolución «hizo suya la democracia, contagiándola de su homogeneizadora sustancia igualitarista» ${ }^{36}$.

El Estado, que nace bajo la entelequia fundacional del contractualismo, una quimera social, posee un fin escatológico propio solo materializable a través de la política; de ahí que las ideologías, como religiones de lo político, ofrezcan como decimos, a modo de trasunto prometeico de la religión tradicional, una teleología utópica de salvación ${ }^{37}$. La construcción de escenarios escatológicos terrenales y paraísos seculares responde al ineluctable vaciamiento metafísico fruto del cambio de paradigma y la introducción de un nuevo arquetipo antropológico. La lucha contra el mal dentro y fuera del Estado opera de modo análogo a la absolución del pecado dentro del cristianismo, aunque en el caso de las religiones estatales no se persigue el perdón sino la erradicación del mal: el mal ha de ser extirpado quirúrgicamente del mundo. Esto responde a la idea gnóstica de que el mundo ha sido creado imperfecto y es el hombre redentor el que ha de restaurarlo ${ }^{38}$, lo que por cierto remite a una remota idea de Dios creador $^{39}$. Todas las ideologías han presentado su propia versión del pecado, siempre bajo una tensión dialéctica, bien de la clase o de la raza, bien bajo la tensión entre lo moral y lo inmoral, siendo la moral estatal una moral pública política y por lo tanto neutral. Por cierto que la moral no puede ser neutral, puesto que la moral siempre está de acuerdo con un orden objetivo. La moral de Estado versa sobre lo políticamente correcto o incorrecto, a expensas de la legalidad, que por otro lado se presume siempre legítima, aunque no se sustraiga a su propio origen convencional. Porque la ley estatal, a diferencia del Derecho, es convencional, y el Derecho, que

${ }^{36}$ Ibid., p.228.

37 Anteriormente se ha definido las religiones seculares como «aquellas formas de sacralización de lo temporal, cuya principal característica es ofrecer una dimensión escatológica intramundana solucionada a través de la política y del Estado, al mismo tiempo que se presentan a sí mismas como detentoras de un orden del ser y del mundo inmanente, que sugiere un nuevo arquetipo humano divinizado pero no trascendente, con capacidad autorredentora puesta al servicio de una teleología utópica de perfección que persigue el paraíso secular en la tierra». Para más información a este respecto, ver: Gallego Pérez de Sevilla, Francisco de Borja, «Religión secular y utopía: la búsqueda de una definición». Revista de Derecho Público Iberoamericano 9 (2016) p. 147.

${ }^{38}$ Ciencia política y gnosticismo. Dos ensayos, VOEGELIN, Eric. Trotta, Madrid, 2014, pp.127-128.

${ }^{39}$ Ciencia política y..., VOEGELIN, Eric, op. cit., pp. 198-199. Explica el autor que «la idea de perfección de los movimientos gnósticos de masas - religiones políticas- tiene pues, un origen cristiano». Aunque para el cristianismo la perfección no puede darse en este mundo «sino únicamente en la visión beatifica, en la perfección sobrenatural que se alcanza por la gracia en el momento de la muerte». 
es el reflejo positivo y adecuado a los hombres de la ley natural, posee siempre una ulterior legitimidad supra-convencional, así como la tiene el imperio que responde a la idea de un orden cósmico, como ya dijimos. Por eso el Estado o un conjunto de Estados no puede ser un imperio, en todo caso un conjunto de naciones, aunque la nación política neosacralizada opera como un Estado ya que comparte su sustancia artificial, y el acervo, la historia y la cultura común que pretendidamente se exhiben como justificadoras de la nación están ideologizadas, y no sirven más que al Estado, que, como el Dios escondido en las estrellas hobbesiano, siempre está ahí, aunque aparentemente no tome parte del mundo y solo intervenga en una situación excepcional a través del milagro político, como ocurre actualmente con los organismos supra-estatales.

\section{LA DESPOLITIZACIÓN DE LO POLÍTICO Y LA POLITIZACIÓN DE LA NATURALEZA HUMANA}

Lo político es custodio del orden social y responde a la necesidad humana de agruparse y asegurar su supervivencia, tanto física como espiritual; de ahí que las ciudades, la primera de todas las formas políticas, se construyesen casi siempre alrededor de un templo. En las primeras civilizaciones se producían actos de sacralización del poder temporal, y a menudo el régimen político más común era la teocracia. No obstante, lo político, imbuido de espiritualidad, no se inmiscuía en materia escatológica; esto dependía de los dioses. La revolución cristiana ${ }^{40}$ que distinguía entre poder espiritual y poder temporal organizó el mundo medieval y el modo de pensar teológico durante siglos, si bien hasta el siglo XIII no se determinó la diferencia entre mundo natural y sobrenatural, cuya relevancia es comparable al paso del mito al logos del mundo clásico. La sociedad estaba organizada alrededor de la idea del bien común, que no era otra cosa que una meta escatológica. Lo político, pues, gravitaba en torno a una idea espiritual. La irrupción del Estado, que también es revolucionario en un sentido opuesto al cristianismo, confundiría la distinción entre auctoritas y potestas ${ }^{41}$ al refundir ambas en la figura de jefe de Estado, encarnado por un monarca que compartía la sustancia onto-

${ }^{40}$ Negro Pavón, Dalmacio. «La gran Contrarrevolución contra la gran Revolución». Razón Española 185 (2015) p. 21. Para el profesor Dalmacio Negro, la gran primera revolución de la humanidad fue el cristianismo al introducir el perdón de los pecados y el mandamiento del amor. De ahí que se refiera al resto de revoluciones, incluyendo la francesa, como contrarrevoluciones.

${ }^{41}$ Negro Pavón, Dalmacio, La gran Contrarrevolución...op. cit., p. 27. 
lógica del Estado, y cuya potestad se creía divina. Con el asalto ideológico tras la Revolución Francesa, esa sustancia fue transferida a la nación, tal y como hemos venido explicando a lo largo de este trabajo. La sustancia divina ahora quedaba asumida por la nación-Estado, compuesta cuantitativamente por la masa, un fenómeno inédito y antipolítico, y lo divino pasó de ser el objeto de lo político a ser en esencia lo político. De ahí que lo político, al divinizarse, se despolitizase ${ }^{42}$.

Lo político despolitizado genera un nuevo paradigma humano al que antes nos hemos referido; aquel que surge de la estatalidad pero con una nueva dimensión, puesto que ya no es el súbdito del Estado absoluto, - que bien pertenecía al modo de pensar estatal pero no estaba politizado, pues conservaba su independencia frente a lo político-espiritual-, sino que ahora es el hombre-ciudadano, un nuevo arquetipo antropológico dotado de toda una nueva categoría de significación (anti) metafísica marcada por el subjetivismo. Lo humano es ahora una unidad ontológica independiente susceptible de múltiples imputaciones impuestas por el Estado, que actúa como dios providencial esencialmente a través del lenguaje jurídico. A este respecto, escribe José Luis Muñoz de Baena:

«En una concepción nominalista del mundo, donde toda realidad se resuelve en la percepción porque lo nouménico ha desaparecido, el lenguaje goza del poder de imponer un orden al mundo a través de la creación de objetos formales sin fundamento ${ }^{43}$.»

Y añade:

"Con respecto al sentido de la imputación (que es, no en vano, un acto de voluntad), Kelsen sostiene que ésta significa la atribución, no de una conducta a una persona (así, a alguien se le imputa un delito), sino de una consecuencia positiva o negativa (así, a alguien se le imputa un castigo por haber realizado una conducta tipificada como

${ }^{42}$ Schmitt, Carl, Teología... op. cit., p. 178. Señala José Luis Villacañas en el apéndice a la Teología Política de Schmitt que: «La desteologización contiene una despolitización. Al encontrar en la ciencia, en algo debido a la propia actividad del ser humano, la forma de la deificatio, la modernidad no solo rechazó la premisa gnóstica de que en este mundo no hay nada salvador, sino que asumió la forma trinitaria ahora aplicada al ser humano, como metáfora de su historia de salvación: éste era su propio creador, su propio salvador, generaba su propio futuro, hacía de un mundo material un nuevo paraíso por su propia fuerza, y se encargaba a sí mismo de realizar la promesa de salvación cristiana. El ser humano era el Padre, el Hijo y el Espíritu. Había reocupado los lugares de la teología. Había arruinado la trascendencia del mundo».

${ }^{43}$ La abstracción del mundo: sobre el mal autoinmune de la juridicidad moderna, MUÑOZ DE BAENA, José Luis. Centro de Estudios Políticos y Constitucionales, Madrid, 2018, p. 254. 
delictiva); la referencia de la imputación a la voluntad de quien imputa es el motivo de que en ella exista un punto final, que no se da en la causalidad $(\ldots)^{44}$.»

El hombre posmoderno, bajo la carta blanca del voluntarismo jurídico que proporciona la subjetividad, puede aceptar y rechazar la naturaleza e incluso modificarla a capricho puesto que antepone el accidente a la esencia, y hace del accidente la esencia misma de su yo subjetivo, lo que apunta a una forma de solipsismo radical que disuelven la relación entre materia y forma. La materia se vuelve prescindible y la forma "construye lingüísticamente el orden. Un orden que entraña la formalización del poder, la auto-referencia» ${ }^{45}$. El lenguaje aparece otra vez como elemento fundamental en el sistema de imputaciones al configurar una constelación de infinitas posibilidades. Toda imputación es potencialmente posible, del mismo modo que «toda subjetividad es imputación» ${ }^{46}$. En el mismo sentido, explica Muñoz de Baena:

«(...) Pues ese lenguaje es el trasunto de un sujeto soberano que designa, al modo nominalista, sin fundamento in re. El lenguaje es así, en un mundo fenoménico cuya equivocidad es absoluta, el resultado de la ausencia de significado estable de las $\operatorname{cosas}^{47}$.»

Esta politización humana supone la radical asunción del nihilismo: es el hombre fundado en la Nada y cuya religión se asienta en la Nada ${ }^{48}$; y como la Nada es voluble y maleable, el hombre nuevo puede ser construido a capricho por la ingeniería social y el aparato ideológico dominante, que determina la naturaleza del individuo: «la subjetividad no es ya el dato previo, sino el resultado de una imputación del sistema jurídico que ni siquiera requiere la voluntad del imputado, sino sólo el mandato de quien imputa ${ }^{49}$.»

\section{LA ERA DE LA IMITACIÓN}

Si la modernidad se define en esencia por la presencia del Estado y la revolución ideológica que sacralizó al hombre y dio lugar a las religiones de lo político, que no son sino trasuntos politizados de culto hacia lo exclusivamente mundano, la posmodernidad viene

${ }^{44}$ Ibid., pp. 255-257.

45 Ibid., p.258.

46 Ibid., p.258.

${ }^{47}$ Ibid., p.259.

${ }^{48}$ El mito del hombre nuevo, NEGRO, Dalmacio. Ediciones Encuentro, Madrid, 2009 , p. 150.

${ }^{49}$ Muñoz de Baena Simón, José Luis, La abstracción...óp. cit., p. 261.

(c) UNED. Revista de Derecho UNED, núm. 24, 2019 
marcada por la prórroga de esta situación con el principal ingrediente de la imitación como instrumento político. Resulta muy sugerente la tesis del antropólogo francés René Girard sobre la crisis mimética y el primer acto de violencia fundacional de toda sociedad, que actúa como remedio catártico de la rivalidad mimética a través del sacrificio del chivo expiatorio, cuya muerte purga los males de aquella. Explica el autor:

«La condensación de todos los escándalos separados en un escándalo único constituye el paroxismo de un proceso que comienza con el deseo mimético y sus rivalidades. Al multiplicarse, estas suscitan una crisis mimética, la violencia del todos contra todos, que acabará por aniquilar la comunidad si, al final, no se transforma de manera espontánea, automáticamente, en un todos contra uno gracias al cual se rehace la unidad ${ }^{50}$ ».

Girard se refiere a escándalos como el fruto inevitable del celo mimético, cuyas pulsiones son tratadas de reprimir legislativamente. La idea del deseo metafísico y su represión social aparece como denominador común desde los albores de la civilización. Pero, ¿de dónde procede la crisis mimética? Explica Domingo González que en la dinámica triangular del mecanismo mimético, aparecen tres elementos decisivos: el yo, el objeto y el modelo a imitar, el otro. La primera fase del deseo incide sobre el objeto; sin embargo, en esta relación de alteridad la importancia del objeto, o bien es prescindible, o queda relegada a un segundo plano, de tal modo que el deseo de imitación trasciende sobre el modelo que poseía aquel objeto, a lo que Girard se refiere como deseo metafísico, lo que genera la rivalidad mimética ${ }^{51}$. El grado de intensidad de ese deseo vendrá definido por la «virtud metafísica» del deseado, generalmente medida en términos de prestigio social. Cuanta más distancia haya entre el deseado y el mediador, menos enconada será la rivalidad, lo que el autor define como mediación externa. Al contrario, cuanto menor sea la distancia entre ambos sujetos, más intensa será la rivalidad y el deseo metafísico, siendo éste el escenario de la mediación interna. ${ }^{52}$ Este deseo metafísico se mueve en el ambiguo territorio entre la admiración y el resentimiento, puesto que la rivalidad no nace sino del deseo mimético sobre el otro, sobre su «autonomía metafísica ${ }^{53}$, lo que le confiere una cierta dimensión espiritual.

${ }^{50}$ Veo a Satán caer como al relámpago. GIRARD, René. Anagrama, Barcelona, 2012, pp. 43-44.

${ }^{5}$ René Girard, maestro cristiano de la sospecha, GONZÁLEZ, Domingo. Persona, Salamanca, 2016, p.72.

52 Ibid., p.74.

53 Ibid., p.72. 
Se deduce fácilmente que para el autor — puesto que deseamos lo accesible y no aquello que escapa a nuestras posibilidades-, las sociedades más igualitarias y con menos desajustes sociales son aquellas más susceptibles al estallido de una crisis mimética, y por lo tanto las menos deseables. De ahí que Girard haya sido, entre otras razones, blanco de numerosas críticas.

En fin, la urgencia social del chivo expiatorio se exacerba cuando la escalada mimética se hace insostenible y amenaza con destruir la comunidad. El autor subraya la importancia a de este «asesinato fundacional» como generador de la política en contraposición al mito moderno del contrato social ${ }^{54}$. Resulta llamativo sin embargo que la situación de violencia mimética descrita por Girard coincide con el estado de naturaleza hobbesiano del «todos contra todos»; si bien la resolución para Hobbes pasa por la construcción del Leviatán que neutraliza el conflicto mediante la política, para Girard es la propia sociedad la que filtra esa violencia mediante el acto sacrificial cuya dimensión sagrada no es fruto de lo político, sino que genera lo político en sí mismo. De ahí que Girard sostenga que las sociedades humanas son "hijas de lo religioso».

Bajo este escenario, las sociedades repetirían de manera simbólica el acto sacrificial para protegerse de la violencia, aunque esto implicase mantener la mentira arcaica o «méconnaissance», término francés empleado por Girard — cuya traducción respondería desconocimiento ${ }^{55}$ - y que no es otra que aquella que oculta la inocencia de la víctima. Esta mentira que Girard etiqueta como mentira romántica en contraposición a la verdad novelesca ${ }^{56}$, será revelada por el cristianismo a través del sacrificio de Cristo, la primera víctima reconocida inocente -el cordero de Dios, en contraposición al uso negativo del chivo expiatorio ${ }^{57}$, propia de la terminología judía-.

${ }^{54}$ Girard, René, Veo caer...op. cit., pp.128-130.

55 No obstante, para el profesor González, el término «méconnaissance» debe traducirse como mal conocimiento. González Hernández, Domingo, René Girard... op. cit., p. 56.

56 Ibid., 76. Escribe Domingo González en referencia a la verdad novelesca: «Según Girard, los Cervantes, Flaubert, Stendhal, Dostoievski y demás novelistas del deseo viven "en un auténtico laboratorio de observación histórica y sociológica". Se mantiene la estructura triangular del deseo pero la gran literatura novelesca relata la superación del umbral metafísico, el paso de la mediación externa a la interna, el triunfo del prestigio y el ser del modelo sobre las virtudes metafísicas del objeto". En contraposición, la mentira romántica no solo ocultaría la gravedad de la violencia del sacrificio, sino todo el mecanismo mimético negando la posibilidad del salto «físico» del objeto al «metafísico» del modelo.

57 Girard, René, Veo a Satán...op. cit., p. 201. 
Al desvelar la naturaleza de la mentira fundacional y disipar la «méconnaissance», el cristianismo desmitifica el mundo antiguo y desacraliza la institución pagana del sacrificio, recuperada posteriormente por el mundo moderno:

«La Pasión de Cristo reproduce la misma violencia unánime que golpea a las comunidades amenazadas por las crisis miméticas recurrentes, pero su resolución solo puede entenderse por la irrupción de la Gracia, que rompe la dinámica envolvente del mimetismo conflictivo con la proclamación pacífica y benigna del Reino de Dios, capaz de reconciliar a los hombres sin recurrir a la violencia fundacional (...) Frente a la celebración mítica de la violencia de las muchedumbres y a la proclamación, primero, de la culpabilidad de la víctima, y después, de su sacralización, el Evangelio denuncia a los perseguidores y defiende la inocencia de la víctima ${ }^{58}$ ».

Pero del mismo modo que el cristianismo desvela y denuncia la mentira de la violencia fundacional, introduce la posibilidad del conflicto, puesto que anula automáticamente los mecanismos mediante los cuales las sociedades neutralizaban la violencia ${ }^{59}$. En este sentido, para Girard el cristianismo representa todo lo bueno y todo lo malo, igual que la propia dinámica del deseo metafísico, que bien introduce la envidia y el rencor patológico sobre el modelo a imitar, bien supone el deseo de progreso y de mejora personal. Esta ambivalencia también se encuentra en el propio acto de sacrificio al que el autor se refiere como pharmakos, en tanto que, tal y como una vacuna que inocula un virus en el cuerpo, aquél introduce la violencia en la sociedad para precisamente curarla de la misma ${ }^{60}$.

En cualquier caso, lo interesante de esta tesis para el trabajo que nos ocupa no es tanto el proceso de rivalidad mimética que desemboca en la causalidad mágico-persecutoria ${ }^{61}$ y finalmente en el sacrificio del chivo expiatorio, sino en la imitación ideológica del sacrificio cristiano y la lógica victimaria como instrumento político de masas, extrapolable a la idea de Estado como katéchon. Resulta interesante subrayar que el sentido de revelación en Girard contiene un tono eminentemente apocalíptico en el sentido original del término, y que precisamente el katéchon se encontraría en aquellas instituciones que, una vez desvelada la mentira mítica, retienen la violencia y la llegada del anticristo en el apocalipsis:

\footnotetext{
58 González Hernández, Domingo, René Girard...op. cit., p. 150.

59 Ibid., p.159.

${ }^{60}$ Ibid., p.104.

${ }^{61}$ Léon Poliakov también se refiere a la lógica victimaria con el sugerente apelativo de "causalidad diabólica».
} 
«En la Epístola a los Tesalonicenses Pablo define lo que retrasa el «desencadenamiento de Satán» como un katéchon o, dicho de otra forma, como lo que contiene el Apocalipsis (...) Se trata, forzosamente, de un conjunto en el que las cualidades más contrarias armonizan, tanto la fuerza de inercia de las potestades de este mundo como su facultad de adaptación, tanto su incomprensión como su comprensión de la Revelación. Y el retrato del Apocalipsis tal vez de deba igualmente, o quizá sobre todo, al comportamiento de los individuos que se esfuerzan en renunciar a la violencia y no fomentar el espíritu de represalia ${ }^{62}$ ».

Como el pharmakos, el Apocalipsis también alberga una cierta ambivalencia, en tanto presupone la revelación de los misterios escatológicos del cristianismo pero también el final del mundo. También la misma imitación de Cristo presupone ambigüedad; por un lado, la imitación de los santos, y por otra, la imitación ideológica que se arroga la legitimidad moral del sacrificio; lo que por cierto se transfiere al lenguaje ideológico estatal, que al tiempo que denuncia la violencia de algunos, victimiza a otros. Como dice el propio Girard:

«Vivimos en un mundo (...) que no hace más que reprocharse de manera sistemáticamente, ritual, su propia violencia. Y nos las arreglamos para transponer nuestros conflictos, incluso los que menos se prestan a esa transposición, al lenguaje de las víctimas inocentes. El debate sobre el aborto, por ejemplo: sea a favor o en contra, siempre elegimos nuestro campo de interés de las «verdaderas víctimas ${ }^{63} . »$

Esta tesis nos ofrece un sugerente escenario, que introduce la idea de la era de la imitación donde se sitúan el Estado y el hombre nuevo como la gran obra magna del proceso mimético; el hombre nuevo como imitador de Cristo y redentor del pecado del mundo, y el Estado como iglesia-katéchon en el mundo que retiene el mal.

El holocausto de Cristo por el perdón de los pecados resquebraja el rito del sacrificio y pone fin a toda retribución introduciendo el elemento radical de la sacralización de la víctima, lo que para el modo de pensar estatal constituye un fenómeno social típicamente posmoderno: el surgimiento de minorías consideradas víctimas y por ende divinizadas, con legitimidad para reclamar aquello que entienden ha sido arrebatado; generalmente un derecho o privilegio del que bien creen carecer o del que bien creen injusto que disfrute el otro, ya sea por razón de género, clase social o raza. Al final,

${ }^{62}$ Girard, René, Veo a Satán...op. cit., p. 240.

${ }^{63}$ Ibid., p. 228. 
el proceso de rivalidad mimética vuelve a reproducirse y la escalada de tensión es ineluctable: las supuestas víctimas buscan nuevos chivos expiatorios para descargar la violencia hasta entonces frustrada, y lo harán con todo el aparataje judicial e ideológico que esté a su alcance, buscando como justificación un delito inadmisible para la religión atea del Estado.

Porque en efecto, todas las religiones ideológicas encontraron dentro de sus particulares teodiceas sus propias hagiografías, mártires, causas y pecados; si para la dialéctica marxista el pecado era la propiedad privada y los pecadores la clase capitalista, o para el nacional-socialismo el mal se encontraba en un delito de nacimiento, para la posmodernidad jurídica del Estado el pecado se halla en la incorrección política y en la insumisión moral de las doctrinas del modo de pensar neutral y neutralizador. El Estado, a través de la ideología, utiliza todos los recursos legales y sociales para neutralizar el pecado, siendo la naturaleza humana el último campo de batalla, la última conquista, puesto que en la inmutabilidad ontológica de la naturaleza humana se halla la mayor de las blasfemias; que ha de ser subsanada mediante la politización, que bien puede ser entendida como el estadio final de la secularización tanto política como antropológica de la modernidad. Y en la posmodernidad el hombre alcanza un nuevo y revolucionario estado; ya no es político, es política en sí mismo, es producto de la política y el eschaton hacia el que se dirige es intrahistórico, el paraíso secular en la tierra ahora materializado y radicalizado bajo la tuición del Estado-katéchon capaz de neutralizar el mal.

\section{CONCLUSIONES}

Hemos analizado la idea de Estado como trasunto secularizado y mundano del concepto de katéchon, que aparentemente no retiene la llegada del mal, sino que lo enmascara, puesto que para el Estado el mal es una situación política. Empero, es importante subrayar que en el sentido más puro de la imitación, el Estado si posee la facultad de contener el mal en tanto es capaz abrogarlo jurídicamente, siendo éste el ulterior objetivo como prurito de sociedad perfecta. El mensaje apocalíptico del katéchon no se sustrae del lenguaje estatal ideologizado de las religiones políticas. El fin del eón cristiano representa la parusía que para el modo de pensar posmoderno es la llegada del hombre nuevo como redentor del mundo. La escatología intramundana del Estado determina el ca- 
mino de la política hodierna, diseñada para conducir al hombre hasta los altares de lo político y dominar así científicamente la historia y con ello su propia existencia, cuya autonomía ontológica sugiere una mutabilidad metafísica absoluta.

La politización de lo humano se deduce de la despolitización de lo político, fruto de su sacralización. Lo divino queda encerrado dentro de los confines intrahistóricos, determinados por la política estatal. Lo político se extingue cuando nace la política como ciencia de la neutralización y cuando el Derecho deviene en legislación, que burocratiza y normativiza la vida. La impoliticidad que ofrecía la situación de paz proporcionada por el imperio queda reemplazada por la impoliticidad del katéchon político.

La noción del katéchon cristiano imperial queda neutralizada y disuelta bajo el mundialismo ideológico y el fenómeno de la supraestatalidad. El peor temor de Schmitt —el aniquilamiento de los grandes espacios diferenciados y el surgimiento de un one worldparece materializarse a un ritmo vertiginoso con la creación de un único y babilónico espacio polarizado, neutral y neutralizador, cuyo protagonista indiscutible es el Estado y la multiplicidad de órganos interestatales que de él se derivan. Pese a ser un concepto abstracto y artificial, se erige como un poder omnímodo y auto-legitimado que se arroga el papel de guardián del mundo, algo aparentemente paradójico puesto que el Estado se define, entre otras cosas, por su particularismo. Sin embargo, el universalismo —el anomos schmittiano- avanza inexorablemente bajo la forma estatal al tiempo que mantiene una dialéctica de tensión mimética con la Iglesia, no solo por la imitación de su universalidad sino por la asunción de sus fines escatológicos particulares.

Asimismo, la Iglesia, que en su complejidad dicotómica, se sitúa en el centro de la aporía intelectual que presupone el katéchon como figura teológico-política ambigua, que por un lado retiene la llegada del Anticristo y por otro lo enmascara dentro de aquella esperando a ser revelado en el fin de los tiempos, tal y como hace el Estado, si bien éste organiza su propio tiempo mesiánico que se resuelve ideológicamente.

En fin, en esto reside el drama -o paradoja, si se quiere- del mysterium iniquitatis y del mismo katéchon: la ineluctable llegada del mal que se hace necesaria para la parusía de Cristo, el Bien de bienes para la cristiandad; de cómo del mal puede surgir el bien, siendo el Apocalipsis tiempo de temor escatológico pero también de júbilo. 


\section{BIBLIOGRAFÍA}

Agamben, Giorgio, (2013). El misterio del mal. Benedicto XVI y el fin de los tiempos. Buenos Aires, Adriana Hidalgo editora.

Agamben, Giorgio. (2008). El reino y la gloria. Por una genealogía teológica de la economía y el gobierno. Valencia, Pre-Textos.

Buela Lamas, Alberto. 2008. «El katéchon como idea metapolítica». Última modificación 18 de noviembre. http://euro-synergies.hautetfort.com/archive/2008/11/18/el-katechon-como-idea-metapolitica.html

Gallego García, Elio A. (2016). Autoridad y Razón: Hobbes y la quiebra de la tradición occidental. Madrid, Estudios Políticos.

Gallego Pérez de Sevilla, Francisco de Borja. (2016). Religión secular y utopía: la búsqueda de una definición. Derecho Público Iberoamericano (9), pp. 128-148.

Galindo, Alfonso. (2005). Política y Mesianismo: Giorgio Agamben. Madrid, Biblioteca Nueva.

Gentile, Emilio. (2006). Politics as religions. Traducción de George Saunton, Princetown University Press.

GIRARD, René. (2012). Veo a Satán caer como el relámpago. Barcelona, Anagrama.

González Hernández, Domingo. (2016). René Girard, maestro cristiano de la sospecha. Salamanca, Persona, 2016.

Hegel, Friedrich. (1993). Fundamentos de la filosofía del derecho. Madrid, Libertarias-Prodhufi.

Jiménez Segado, Carmelo. (2009). Contrarrevolución o resistencia: la teoría política de Carl Schmitt. Madrid, Tecnos.

Muñoz de BaEna Simón, José Luis. (2018). La abstracción del mundo: sobre el mal autoinmune de la juridicidad moderna. Centro de Estudios Políticos y Constitucionales, Madrid.

Negro Pavón, Dalmacio. (2009). El mito del hombre nuevo. Madrid, Ediciones Encuentro.

Negro Pavón, Dalmacio. (2010). Historia de las formas del Estado. Una introducción. Madrid, El Buey Mudo.

Negro Pavón, Dalmacio. (2015). La gran Contrarrevolución contra la gran Revolución. Razón Española (185), 21. 
Schmitt, Carl. (2009). Teología Política. Madrid, Trotta.

Schmitт, Carl. (2007). Tierra y mar. Madrid. Trotta

Schmitт,Carl. (2016). El concepto de lo político. Madrid, Alianza Editorial.

Schmitт, Carl. (2011). Catolicismo Romano y forma política. Madrid, Tecnos.

Schмiтt, Carl. El nomos de la tierra en el Derecho de Gentes «Jus publicum europaeum». Buenos Aires, Editorial Struhart \& Cía.

Voegelin, Eric. (2014). Las religiones políticas. Madrid, Trotta.

Voegelin, Eric. (2014). Ciencia política y gnosticismo. Dos ensayos. Madrid, Trotta.

WALZER, Michael. (2008) La revolución de los santos: estudio sobre los orígenes de la política radical. Madrid, Katz Editores. 